\title{
Histological Features and Tissue Microarray Taxonomy of Nigerian Breast Cancer Reveal Predominance of the High-Grade Triple-Negative Phenotype
}

\author{
N.A. Titloye ${ }^{a}$ A. Foster ${ }^{\text {g }}$ G.O. Omoniyi-Esan ${ }^{\text {b }}$ A.O. Komolafe ${ }^{b}$ A.O. Daramolac \\ O.A. Adeoye ${ }^{d} \quad$ A.O. Adisab ${ }^{b} \quad$ A. Manoharan' $\quad$ D. Pathak ${ }^{g} \quad$ M.N. D'Cruz ${ }^{9}$ \\ Y. Alizadeh ${ }^{9}$ P.D. Lewis ${ }^{\text {e A.M. Shaaban }}{ }^{f}$

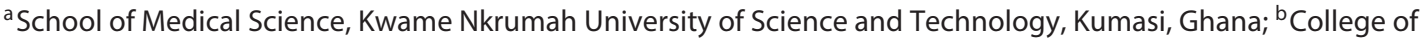 \\ Health Sciences, Obafemi Awolowo University, Ile-Ife, 'C College of Medicine University of Lagos, Lagos, and \\ ${ }^{\mathrm{d}}$ College of Medicine University of Ibadan, Ibadan, Nigeria; ${ }^{e}$ College of Medicine Swansea University, Swansea, \\ ${ }^{f}$ Queen Elizabeth Hospital Birmingham and University of Birmingham, Birmingham, and ${ }^{9}$ St James's University \\ Hospital, Leeds, UK
}

\section{Key Words}

Breast cancer · Tissue microarray · Estrogen receptor expression

\begin{abstract}
Introduction: Little is known about the biology, molecular profile and hence optimal treatment of African Nigerian breast cancer. The aim of this work, therefore, was to characterize the histology and molecular profile of Nigerian breast cancer. Methods: Breast carcinomas from women at 6 centres of similar tribal origin in Nigeria were reviewed and assembled into tissue microarrays (TMAs), and sections were stained for hormone receptors, i.e. estrogen receptor (ER)a, $E R \beta 1$, ER $\beta$ progesterone receptor (PR) and androgen receptor, cyclin D, HER2, Ki67 and cytokeratins (CKs), i.e. CK5/6 and CK14 (basal) and CK18 and 19 (luminal). Results: A total of 835 tumours were analysed. The mean age at diagnosis was $48.62 \pm 12.41$ years. The most common histological subtype was ductal NST (no-special-type) carcinoma (87.3\%). Over
\end{abstract}

\section{KARGER}

E-Mail karger@karger.com

www.karger.com/pat
$90 \%$ of the tumours were grade 2 or 3 . The predominant molecular phenotype was the non-basal, triple-negative type (47.65\%) followed by the HER2-positive group (19.6\%). The percentage of ER-, PR- and HER2-positive tumours was 22.4, 18.9 and $18.8 \%$, respectively. Conclusion: Nigerian breast cancer predominantly has a high-grade, triple-negative profile. It occurs at a younger age and bears similarities at the molecular level to pre-menopausal breast cancer in white women, with remarkably lower levels of ER $\beta$ expression. The early presentation and histological and molecular phenotype may explain the poor prognosis, and tailoring treatment strategies to target this unique profile are required.

(c) 2016 S. Karger AG, Basel

\section{Introduction}

Breast cancer is a heterogeneous disease with distinct subtypes that have different prognoses. Racial and ethnic differences in incidence, molecular phenotype and prog-
(C) 2016 S. Karger AG, Basel

1015-2008/16/0831-0024\$39.50/0
Dr. Abeer Shaaban, $\mathrm{MBBCh}, \mathrm{PhD}$

FRCPath Dip Health Research, Department of Cellular Pathology Queen Elizabeth Hospital Birmingham, Mindelsohn Way, Edgbaston Birmingham B15 2WB (UK)

E-Mail abeer.shaaban@uhb.nhs.uk 
Table 1. Details of antibodies used in this study

\begin{tabular}{|c|c|c|c|c|c|c|}
\hline Antibody & Source & Clone & Dilution & Control & Staining & Cut-off \\
\hline $\mathrm{ER} \alpha$ & Leica & $\begin{array}{l}\text { NCL-L-ER- } \\
6 \mathrm{~F} 11\end{array}$ & $1: 250$ & breast carcinoma & nuclear & Allred $>2$ \\
\hline ER $\beta 1$ & Serotec & PPG5/10 & $1: 2$ & breast carcinoma & nuclear + cytoplasmic & Allred $>2$ \\
\hline ER $\beta 2$ & Serotec & $57 / 3$ & $1: 20$ & breast carcinoma & nuclear + cytoplasmic & Allred $>2$ \\
\hline PR & Leica & PgR 636 & $1: 800$ & breast carcinoma & nuclear & Allred $>2$ \\
\hline HER2 & $\begin{array}{l}\text { Dako } \\
\text { Novocastra }\end{array}$ & $\begin{array}{l}\mathrm{A} 0485 \\
\mathrm{CB} 11\end{array}$ & $\begin{array}{l}3.6 \mu \mathrm{l}: 4 \mathrm{ml} \\
8.5 \mu \mathrm{l}: 4 \mathrm{ml}\end{array}$ & $\begin{array}{l}\text { breast carcinoma } \\
\text { with } 4 \text { composite } \\
\text { pieces with scores } \\
\text { of } 0,1+, 2+\text { and } 3+\end{array}$ & membranous & $\begin{array}{l}>30 \% \text { IHC or } \\
2+\text { DDISH } \\
\text { amplified }\end{array}$ \\
\hline CK14 & Leica & LL002 & $1: 100$ & prostate & membranous & $10 \%$ \\
\hline CK5/6 & Dako & D5/16 B4 & $1: 100$ & prostate & membranous & $10 \%$ \\
\hline CK8/18 & Leica & NCL-5D3 & $1: 200$ & appendix & membranous & $10 \%$ \\
\hline CK19 & Leica & NCL-CK19 & $1: 100$ & appendix & membranous & $10 \%$ \\
\hline Ki67 & Dako & MIB-1 & $1: 100$ & tonsils & nuclear & $10 \%$ \\
\hline p53 & Leica & D07 & $1: 600$ & bowel carcinoma & nuclear & $10 \%$ \\
\hline Cyclin D & & & & & nuclear & $10 \%$ \\
\hline E-cadherin & Dako & M3612 & $1: 100$ & normal breast & membranous & $10 \%$ \\
\hline
\end{tabular}

Secondary detection of all antibodies was performed with the Dako EnVision kit.

nosis have been identified in breast and other cancers. Studies of Afro-American women have shown a stable incidence of breast cancer. While breast cancer incidence in women $>50$ years has decreased in non-Hispanic whites, it has remained stable in African-American women [1]. The SEER (Surveillance, Epidemiology, and End Results) population-based data and other studies documented a higher incidence of mortality among AfricanAmericans than Caucasian Americans [2-4]. Recent data also suggest biological differences in breast cancer occurring in black women compared to white women in Great Britain [5]. In Africa, breast cancer incidence is rising and is associated with a high mortality rate in comparison to other populations [6].

To date, breast cancer in Africa remains neglected, with only few studies examining the morphological features and the molecular profile of African breast cancer. Most of these studies use patients' records, comprise a small sample size and yield contradictory results $[7,8]$. The aim of this work, therefore, was to characterize the histological features and molecular profile of Nigerian breast cancer in order to gain insight into its biology, and consequently offer potential treatment options. This was done via a multi-institutional study, collecting a large number of Nigerian breast cancer tissues and constructing tissue microarrays (TMAs) of these tumours for the comprehensive analysis of potential diagnostic, predictive and prognostic markers.

\section{Materials and Methods}

Data on Patients and Tissue Collection

Ethical approval was sought and granted (REC No. 06/ Q1206/180). Patients with a diagnosis of primary invasive breast carcinoma in the period between 1990 and 2007 were identified from the pathology database of 6 large laboratories in south-west Nigeria: the Department of Morbid Anatomy and Forensic Pathology, Obafemi Awolowo University, Ile-Ife, the Department of Pathology, Ladoke Akintola University Teaching Hospital, Osogbo, the Department of Pathology, Federal Medical Centre Ido, the Department of Pathology, University College Hospital Ibadan, the Department of Anatomic and Molecular Pathology, Lagos University Teaching Hospital and the Fairview Laboratory, Akure. These serve a relatively homogenous population of Nigerian women of similar origin, i.e. the Yoruba, who reside in the south-western states of Nigeria.

Paraffin blocks of the samples were received anonymised in the UK after local approval from each Nigerian department and no patient consent was needed. All cases were jointly reviewed by a Nigerian pathologist (N.A.T.) and a UK specialist breast pathologist (A.M.S.) following the guidelines of the Royal College of Pathologists [9], to confirm the diagnosis, type of cancer, histological grade and nodal status. Cases with a primary diagnosis of invasive breast carcinoma were included in this study. Metastatic mammary carcinoma and/or carcinoma of non-mammary origin were excluded. Cases of pure ductal carcinoma in situ without invasion were also excluded. The clinical data including patients' age and gender, laterality and tumour size were collected from patients' notes and pathology reports where available. Survival data could not be obtained due to sparse records at the originating hospitals.

\section{TMA Construction}

A manual tissue microarrayer (MTA1, Beecher Instruments, USA) was used to construct the TMAs, using $0.6-\mathrm{mm}$ core punch- 
Table 2. Clinicopathological features of Nigerian patients

\begin{tabular}{|c|c|c|}
\hline Mean age, years & $48.62(\mathrm{SD} 12.41)$ & \multirow{7}{*}{$\mathrm{p}<0.0001$} \\
\hline Age group & $4.73(13)$ & \\
\hline$<30$ years & $24.36(67)$ & \\
\hline $30-40$ years & $33.09(91)$ & \\
\hline $41-50$ years & $23.27(64)$ & \\
\hline$>51$ years & $14.55(40)$ & \\
\hline Mean tumour size & $63.33 \mathrm{~mm}(\mathrm{SD} 1.24)$ & \\
\hline \multicolumn{3}{|l|}{ Histological grade } \\
\hline I & $8.27(34)$ & \multirow[t]{13}{*}{$\mathrm{p}<0.0001$} \\
\hline II & $45.26(186)$ & \\
\hline III & $46.47(191)$ & \\
\hline \multicolumn{2}{|l|}{ Histological type } & \\
\hline Ductal NST & $87.3(420)$ & \\
\hline Lobular & $3.7(18)$ & \\
\hline Metaplastic & $3.1(15)$ & \\
\hline Papillary & $1.87(9)$ & \\
\hline Mucinous & $1.66(8)$ & \\
\hline \multirow[t]{3}{*}{ Medullary-like } & 1.45 (SAS Institute Inc., SAS & \\
\hline & Technical Report P-217 SAS/ & \\
\hline & STAT Software) & \\
\hline Other & $0.83(4)$ & \\
\hline \multicolumn{3}{|c|}{ Nodal status (where stated) } \\
\hline+ & $90.91(50)$ & \multirow[t]{2}{*}{$\mathrm{p}<0.0001$} \\
\hline- & $9.09(5)$ & \\
\hline \multicolumn{3}{|l|}{$\mathrm{ER} \alpha$} \\
\hline+ & $22.4(115)$ & \multirow[t]{2}{*}{$\mathrm{p}<0.0001$} \\
\hline- & $77.6(398)$ & \\
\hline \multicolumn{3}{|l|}{ PR } \\
\hline+ & $18.90(97)$ & \multirow[t]{2}{*}{$\mathrm{p}<0.0001$} \\
\hline- & $81.10(416)$ & \\
\hline \multicolumn{3}{|l|}{ HER2 } \\
\hline+ & $18.87(92)$ & \multirow[t]{2}{*}{$\mathrm{p}<0.0001$} \\
\hline- & $81.13(422)$ & \\
\hline \multicolumn{3}{|l|}{ Molecular subtype } \\
\hline Luminal A & $14.99(70)$ & \multirow{5}{*}{$\mathrm{p}<0.0001$} \\
\hline Luminal B & $5.57(26)$ & \\
\hline HER2+ & $19.65(92)$ & \\
\hline Basal & $12.17(57)$ & \\
\hline Non-basal & $47.65(222)$ & \\
\hline
\end{tabular}

Values expressed as \% (n), unless otherwise indicated. - = Negative; $+=$ positive

es with a 1-mm interval between cores. The method has been described previously $[10,11]$. Briefly, two cores were punched out from the marked areas (the centre and periphery of the tumour, where possible) of the donor blocks and arrayed into the prepunched hole in the recipient block according to the location on the TMA map. From each TMA block, 3- $\mu$ m sections were cut on a microtome (RM2255, Leica) onto SuperFrost Plus slides (Surgipath) and numbered sequentially. To assess core loss or gain as the sections went deeper into the TMA, the 1st, 20th, 40th and last sections were stained with haematoxylin and eosin. This helped identify which sections would contain the highest number of intact cores for immunostaining.

\section{Immunohistochemical Staining}

Standard immunohistochemistry (IHC) was done using a number of antibodies selected based on the available literature and our previous work on predictive and prognostic markers of breast cancer in Western women $[10,12]$. A comprehensive panel of hormone receptors and proliferation and cytokeratin (CK) markers were used to classify breast carcinomas into the 5 recognised taxonomic subtypes [13-15]. A full list of the antibodies used, their sources, clones, dilutions and cut-off values for positivity are provided in table 1.

\section{IHC Scoring}

Estrogen receptor/progesterone receptor/HER (ER/PR/HER) scoring was done following the guidelines of the Royal College of Pathologists and the National External Quality Assessment Service. HER2-positive borderline cases were stained by FISH PathVysion ${ }^{\circledR}$ probe and DDISH (dual-colour, dual-hapten, brightfield in situ hybridisation; Ventana/Roche) to confirm the HER2 amplification status. DDISH was easier to orientate and score and these results were therefore presented and used for the analysis.

Stained IHC slides were scanned digitally using the ScanScope $\mathrm{XT}\left(\right.$ Aperio $\left.^{\mathrm{TM}}\right)$ at $\times 40$ magnification. The IHC slides were scored by 6 UK pathologists (A.M., D.P., M.N.D., Y.A., A.F. and A.M.S.) and 1 senior BMS (A.F.). The DDISH scoring was done by N.A.T. All scoring was overseen by a UK specialist breast histopathologist (A.M.S.).

Following scoring, the tumours were classified based on the expression of ER, PR, HER2, basal markers (CK5, CK14) and Ki67 into 5 taxonomic subtypes as previously described $[16,17]$.

\section{Statistical and Hierarchical Cluster Analysis}

The 5 subtypes were: luminal A (ER-positive and/or PR-positive and ki67-negative/low), luminal B (ER-positive and/or PR-positive and ki67-positive/high), HER2 (HER2-positive, i.e. HER2 overexpression, irrespective of any other marker score), basal triple-negative (ER-, PR- and HER2-negative and either CK5- or CK14-positive) and non-basal (negative for all markers). Pair-wise correlation between various markers was analysed by Spearman correlation using the SPSS statistical package v18. Hierarchical cluster analysis was performed using an asymmetric binary distance measure and a Ward tree-building algorithm in the R statistical programming environment. The variable data were the binary codes for each marker where $0=$ negative, $1=$ positive. A binary (Jaccard) distance measure (d) was calculated as: (count of patients negative for one marker but positive for the other marker)/(count of patients negative for one marker but positive for the other marker + count of patients positive for both markers). Using these distance measures, cluster dendrograms were generated to visualize multivariate similarities between marker scores for each tumour subtype.

\section{Results}

A total of 890 tumours were reviewed, 835 of which fulfilled the inclusion criteria. The clinico-pathological parameters of the study cases are presented in table 2 .

The mean age at diagnosis was 48.62 years with a highly statistically significant difference between the younger 


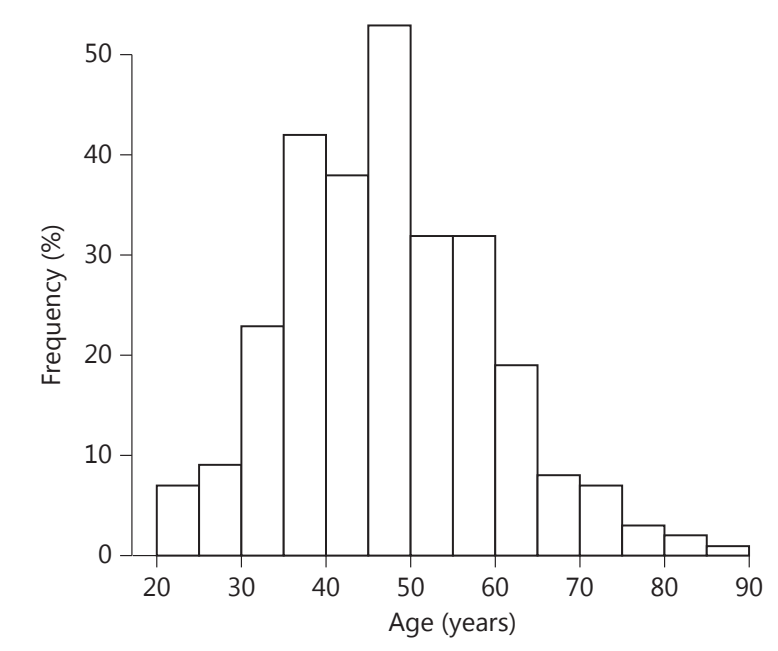

Fig. 1. Age distribution of breast cancer in Nigeria. Most tumours occurred in women $\leq 50$ years of age, with a mean age at diagnosis of 48.62 years.

and older age groups. Over $60 \%$ of patients were $\leq 40$ years at presentation and $85.45 \%$ were $\leq 50$ years.

The age distribution curve shows a pre-menopausal distribution, with the curve extending to the post-menopausal period (fig. 1). The mean tumour size was $63.3 \pm$ $1.24 \mathrm{~mm}$.

\section{Histological Features}

The commonest histological subtype was ductal NST (no-special-type) carcinoma (87.3\%) followed by lobular $(3.7 \%)$ and metaplastic carcinomas (3.1\%), while papillary, mucinous and medullary-like carcinomas accounted for $1.87,1.66$ and $1.45 \%$, respectively. Other very rare subtypes constituted $0.87 \%$ of the total cases (table 2 ).

Histological grade 3 cancers comprised $46.47 \%$ of the cases, while histological grade 2 and 1 comprised 45.26 and $8.27 \%$, respectively. Over $90 \%$ of the tumours were grade 2 or 3 (table 2). There were characteristic histological features including high-grade nuclei, prominent lymphocytic infiltrates and foci of tumour necrosis (fig. 2a).

\section{IHC and Molecular Profile}

The percentage of ER-, PR- and HER2-negative tumours was $77.6,81.1$ and $81.2 \%$, respectively (fig. 2 b, c; table 2).

The most common molecular phenotype was the nonbasal, triple-negative type $(47.65 \%)$, followed by the HER2-positive type (19.6\%). Luminal A was represented in only $14.99 \%$, luminal B in $5.57 \%$ (fig. $2 \mathrm{~d}$, e), while $12.17 \%$ constituted the basal phenotype (fig. $2 \mathrm{f}, \mathrm{g}$ ).

CK14 and CK5/6 were expressed in 14.6 and $9.47 \%$ of the cases, respectively. Expression of these markers was statistically significantly different across various molecular subtypes ( $\mathrm{p}=0.002$ and 0.025 , respectively).

Over half of the tumours were positive for ER $\beta 1$ and ER $\beta 2$ (fig. 2h), with the latter being expressed predominantly in the HER2-positive and non-basal groups ( $\mathrm{p}=$ 0.01 ).

The majority of the tumours expressed the luminal CKs, CK18 and CK19. E-cadherin was predominantly positive in the HER2-positive and non-basal phenotypes compared with the other groups $(\mathrm{p}=0.005)$. Ki67 was highly expressed in almost a quarter of all cases. Most tumours were cyclin D-negative.

The percentage and distribution of positive staining for various markers across the 5 molecular groups are presented in table 3. Basal CKs, nuclear ER $\beta 2$, Ki67, Ecadherin and cyclin D were statistically significantly differentially expressed across various molecular subtypes. ER $\beta 1$ and ER $\beta 2$ cytoplasmic expression, luminal CKs and androgen receptors were not different across subgroups.

\section{Hierarchal Clustering}

Figure 3 shows the hierarchal clustering of markers for the luminal A and basal phenotypes of breast cancer.

Luminal A tumours comprise 2 separate arms: 1 showing clustering of hormone receptors including ER $\beta$ and 1 showing basal clustering with HER2.

Basal tumours (defined as any CK5/CK14 positivity) comprised 2 groups: 1 showing clustering of basal markers with ER $\beta$ and 1 showing clustering of ER, PR and HER2.

\section{Discussion}

We present the largest and most detailed translational study of African breast carcinoma in Nigeria. Our study was conducted on breast tumours from 6 large centres in the southwest of Nigeria, which is inhabited predominantly by the Yoruba ethnic group. This pure ethnicity is important to control for the differences in socio-economic status, access to treatment and therapeutic options offered to patients. All cases were reviewed by a specialist breast pathologist following the UK Breast Reporting Guidelines. We report an early onset of breast cancer, occurring in patients $\leq 50$ years of age in the majority $(>80 \%)$ of cases, and a large proportion with a high-grade, triple- 

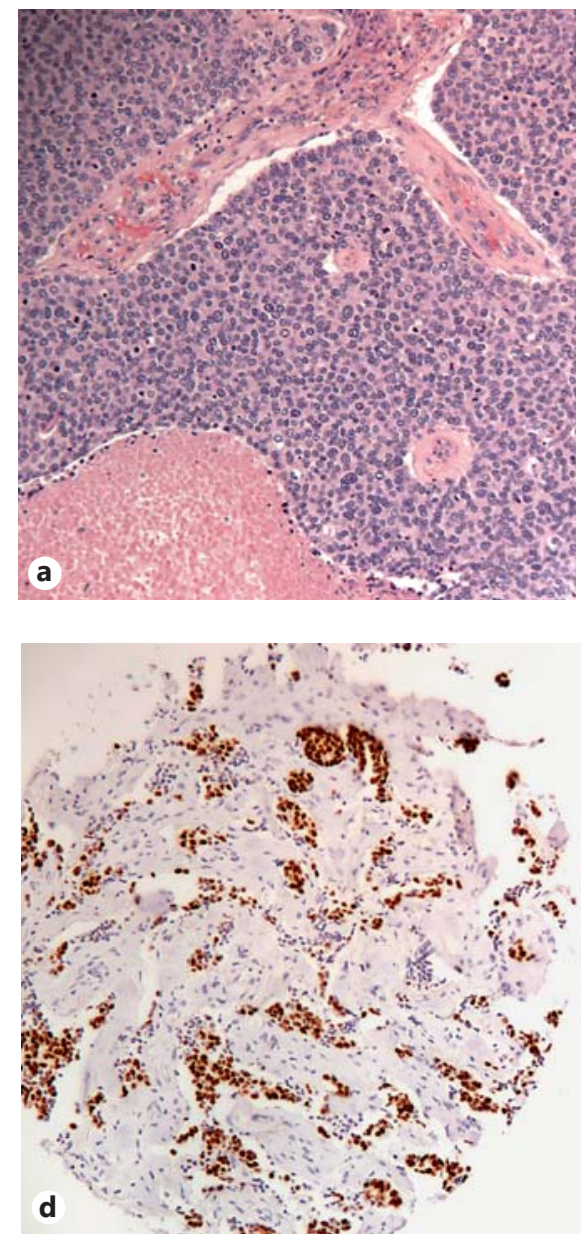

Fig. 2. Typical morphological and IHC appearances of Nigerian breast cancer. a Grade 3 carcinoma showing a syncytial growth, large pleomorphic nuclei, conspicuous mitoses and areas of necrosis. $\mathbf{b}$ ER $\alpha$ negative invasive carcinoma. c HER2-negative invasive carcinoma. d Example of luminal A invasive carcinoma (ER-positive). e Example of luminal B invasive carcinoma (Ki67-positive). Basal phenotype invasive carcinomas show diffuse CK5 positivity (f) and CK14 positivity (g). h ER $\beta$-positive nuclear staining of an invasive carcinoma showing areas of necrosis.
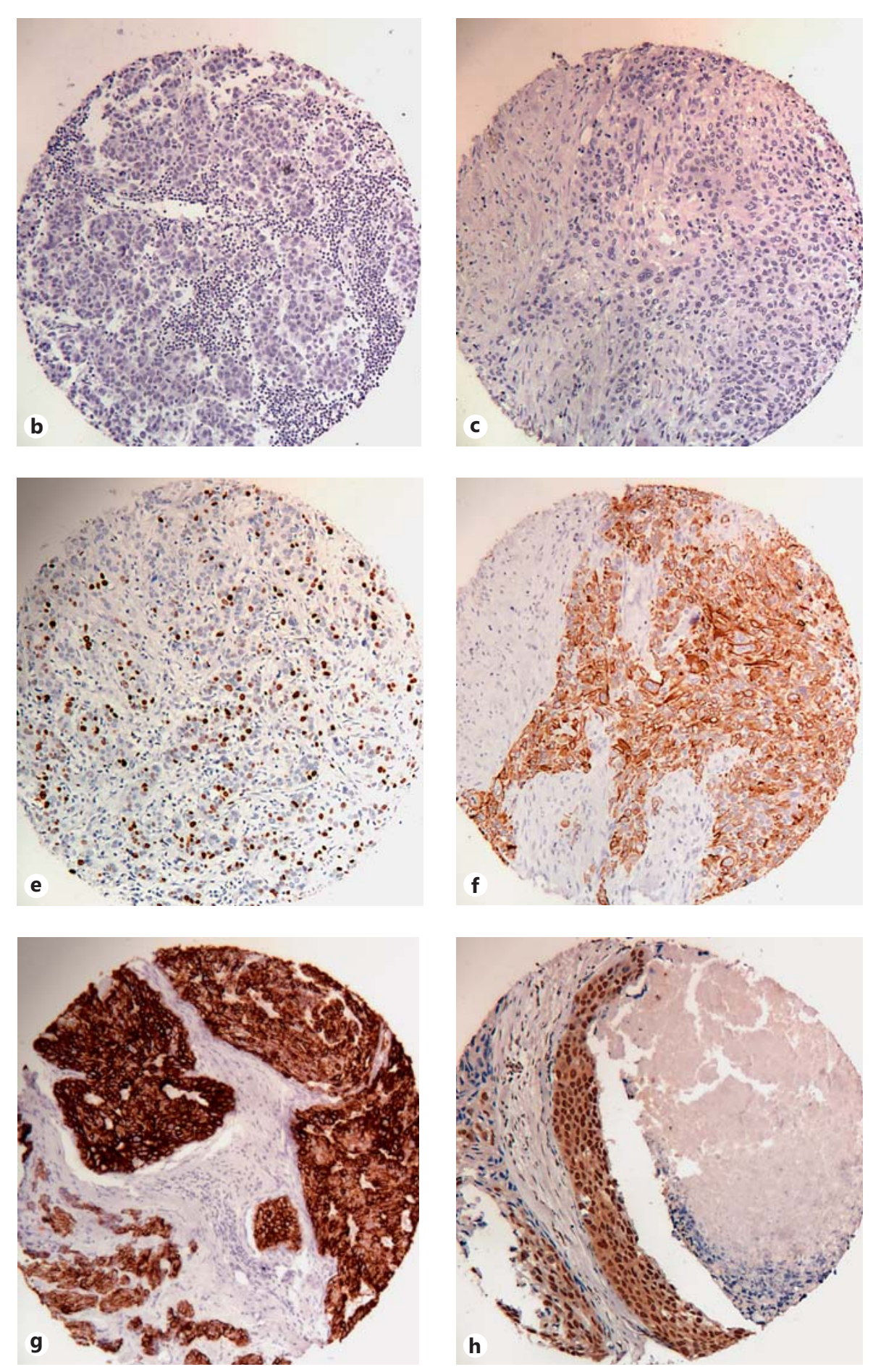

negative profile as well as differential expression of hormone receptors and markers of proliferation and cell cycles across the taxonomic subtypes.

A study of 328 Tanzanian patients reported a mean age at onset of 47.8 years with only $17.4 \%$ of the patients be- ing $>60$ years old [25]. Early onset of breast cancer has been shown in African-Americans and, only recently, also in black women in Great Britain [26]. Using population data from a university hospital in East London in 1994-2005, the black British patients were significantly 
Table 3. Expression of hormone receptors, CKs and proliferation markers according to breast cancer phenotype

\begin{tabular}{|c|c|c|c|c|c|c|c|}
\hline \multirow[t]{2}{*}{ Marker } & \multicolumn{7}{|c|}{ Tumour phenotype } \\
\hline & total & luminal A & luminal B & HER2+ & basal & non-basal & $\mathrm{p}$ value \\
\hline \multicolumn{7}{|l|}{ ER $\beta 1$ Allred } & \multirow[t]{3}{*}{0.1401} \\
\hline- & $37.62(266)$ & $2.74(13)$ & $1.89(9)$ & $5.05(24)$ & $4.00(19)$ & $14.95(71)$ & \\
\hline+ & $62.38(441)$ & $10.95(52)$ & $3.16(15)$ & $13.89(66)$ & $6.95(33)$ & $28.21(134)$ & \\
\hline \multicolumn{7}{|l|}{ ERß2 Allred ${ }^{\mathrm{a}}$} & \multirow[t]{3}{*}{0.0188} \\
\hline- & $42.24(185)$ & $4.21(20)$ & $0.84(4)$ & $3.37(16)$ & $2.53(12)$ & $13.47(64)$ & \\
\hline+ & $57.76(253)$ & $4.21(20)$ & $2.11(10)$ & $10.32(49)$ & $4.42(21)$ & $15.16(72)$ & \\
\hline \multicolumn{8}{|l|}{$\overline{\mathrm{ER} \beta 2}$} \\
\hline cytoplasmic & & & & & & & \multirow[t]{3}{*}{0.8668} \\
\hline- & $56.51(256)$ & $5.68(27)$ & $1.89(9)$ & $7.37(35)$ & $4.21(20)$ & $16.63(79)$ & \\
\hline+ & 43.49 (197) & $3.58(17)$ & $1.05(5)$ & $6.74(32)$ & $3.16(15)$ & $12.84(61)$ & \\
\hline \multicolumn{8}{|l|}{$\overline{\mathrm{AR}}$} \\
\hline- & $86.94(213)$ & $6.11(29)$ & $1.89(9)$ & $7.58(36)$ & $4.42(21)$ & $10.95(52)$ & \multirow[b]{2}{*}{0.5085} \\
\hline+ & $13.06(32)$ & $0.42(2)$ & $0.42(2)$ & $1.89(9)$ & $0.63(3)$ & $1.47(7)$ & \\
\hline \multicolumn{8}{|l|}{$\overline{\mathrm{CK} 8 / 18}$} \\
\hline- & $13.60(74)$ & $1.47(7)$ & $0.63(3)$ & $1.05(5)$ & $1.26(6)$ & $7.16(34)$ & \multirow[t]{2}{*}{0.1126} \\
\hline+ & $86.40(470)$ & $11.58(55)$ & $3.58(17)$ & $15.37(73)$ & $6.53(31)$ & $30.74(146)$ & \\
\hline \multicolumn{8}{|l|}{ CK19 } \\
\hline- & $8.65(50)$ & $0.63(3)$ & $0.63(3)$ & $0.84(4)$ & $1.05(5)$ & $4.42(21)$ & \multirow[t]{2}{*}{0.2558} \\
\hline+ & $91.35(528)$ & $12.42(59)$ & 4.00 (19) & $16.63(79)$ & $7.58(36)$ & $34.53(164)$ & \\
\hline \multicolumn{8}{|l|}{$\overline{C K ~ 5 / 6^{a}}$} \\
\hline- & $90.53(516)$ & $12.84(61)$ & $4.42(21)$ & $14.95(71)$ & $7.16(34)$ & $35.37(168)$ & \multirow[t]{2}{*}{0.0249} \\
\hline+ & $9.47(54)$ & $0.63(3)$ & $0.42(2)$ & $1.47(7)$ & $2.11(10)$ & $3.16(15)$ & \\
\hline \multicolumn{8}{|l|}{$\overline{\mathrm{CK}} 14^{\mathrm{a}}$} \\
\hline- & $85.36(484)$ & $12.63(60)$ & 4.00 (19) & $13.47(64)$ & $6.32(30)$ & 35.58 (169) & \multirow[t]{2}{*}{0.0023} \\
\hline+ & $14.64(83)$ & $0.84(4)$ & $0.84(4)$ & $2.95(14)$ & $2.74(13)$ & $4.00(19)$ & \\
\hline \multicolumn{8}{|l|}{ E-cadherin ${ }^{\mathrm{a}}$} \\
\hline- & $54.52(380)$ & $5.89(28)$ & $1.68(8)$ & $6.53(31)$ & $4.00(19)$ & $25.05(119)$ & \multirow[t]{2}{*}{0.0005} \\
\hline+ & $45.48(317)$ & $7.16(34)$ & $3.16(15)$ & $12.00(57)$ & $6.11(29)$ & $16.84(80)$ & \\
\hline \multicolumn{8}{|l|}{$\mathrm{Ki}^{\mathrm{a}}{ }^{\mathrm{a}}$} \\
\hline Low & $78.81(409)$ & $11.79(56)$ & $3.16(15)$ & $9.68(46)$ & $6.74(32)$ & $28.00(133)$ & \multirow[t]{2}{*}{0.0016} \\
\hline High & $21.19(110)$ & $1.26(6)$ & $1.89(9)$ & $5.05(24)$ & $1.47(7)$ & $6.11(29)$ & \\
\hline \multicolumn{8}{|l|}{ Cyclin D } \\
\hline- & $73.16(229)$ & $7.79(37)$ & $2.32(11)$ & $5.47(26)$ & $2.32(11)$ & $15.37(73)$ & \multirow[t]{2}{*}{0.0045} \\
\hline+ & $26.84(84)$ & $2.53(12)$ & $0.84(4)$ & $4.21(20)$ & $2.11(10)$ & $3.16(15)$ & \\
\hline
\end{tabular}

Values expressed as \% (n). - = Negative; + = positive; AR = androgen receptor. ${ }^{\text {a }}$ Significant parameters.

younger at presentation (median age 46 years) compared with an age of 67 years for the white population. There was no significant difference in the black and white population structure and no other common cancers in black women showed an early onset. On further analysis, Ingleby [27] showed a smaller difference (12 years) in median age at presentation between black and white women. Data from the Second All Breast Cancer Report showed that $45 \%$ of breast cancer in black women occurs between the ages of 30 and 49 years, compared with only $18 \%$ in the white population [28]. A small study comparing the agespecific incidence of breast cancer in Jos in Nigeria $(\mathrm{n}=$ $150)$ and Norfolk in the UK $(n=668)$ showed a mean age at presentation of 43.1 and 64 years, respectively [29]. Overall, Nigeria has a larger population than the UK and a shorter life expectancy (for women, 52.2 and 80.7 years, respectively). The pre-menopausal curve in breast cancer is in sharp contrast with the UK trend that shows a steady rise with age and nearly half $(48 \%)$ of all breast cancers occurring between 50 and 69 years of age [30].

A small study on Tanzanian patients also documented large tumour sizes at presentation (mean $5.5 \mathrm{~cm}$ ) [25]. There are no breast cancer screening programmes in African countries, and therefore the large tumour sizes reported in studies including the mean size in this study, i.e. $6.3 \mathrm{~cm}$, are not unexpected. 
Fig. 3. Hierarchal clustering of the most common groups of Nigerian breast carcinoma. a Luminal A group. b Basal tumours.
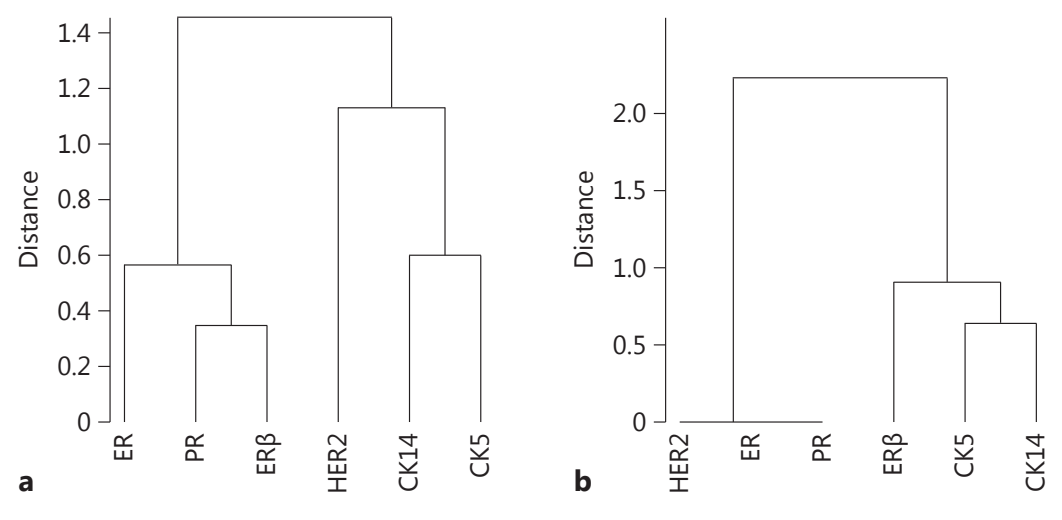

Previous, albeit small, studies of ER/PR/HER2 expression in indigenous populations in sub-Saharan Africa yielded conflicting results (table 4). While the majority reported low levels of positivity, 2 studies, on populations in South Africa and Nigeria, reported a high proportion of ER-positive tumours. The South African study was conducted consecutively on a mixed population including Caucasian, Asian and black patients, with the IHC data being extracted from patients' records. The other study from Ibadan, Nigeria, was conducted prospectively on a small number of patients $(n=192)$. A systematic review and meta-analysis of receptor-defined subtypes of breast cancer in indigenous African populations suggested that the study design, the quality of archival tissue and the methodology of receptor testing were factors that contributed to the conflicting results [23].

The most common molecular subtype in this large cohort of Nigerian breast cancer was the triple-negative phenotype. Luminal A, which is the predominant type of breast cancer in the West, represented only $14.9 \%$ of this cohort. It has been suggested that the ethnic minorities have more protective hormonal risk factors like late menarche, a younger age when giving birth for the first time, high parity and less use of hormonal therapy [31]. Parity has been shown to be protective only for luminal A breast cancer with no effect on the triple-negative group [32]. Bauer et al. [33] found that age was a strong predictor of hormonal status with a significant proportion of the triple-negative cases occurring in patients $<40$ years of age; in another study, 15-18\% of triple-negative breast cancer cases were seen in Americans $>50$ years of age [34]. These factors may explain the lower incidence of luminal A breast cancer and the large proportion of triple-negative tumours in African women.
In contrast to Agboola et al. [18] and Adebamowo et al. [8], the majority of our triple-negative cases (45.67\%) belonged to the non-basal type of breast cancer as they do not express basal CKs (CK5 and CK14). No staining for basal CKs was done in the study by Adebamowo et al. [8] and the triple-negative phenotype was used as a synonym for the basal group. While there is an overlap between these 2 groups, they are not identical, and the classification into basal/non-basal phenotypes should rely on the demonstration of basal CK expression within tumour tissue.

To our knowledge, this is the first report to analyse the expression of ER $\beta$ isoforms in Nigerian and also in African breast cancer cases. We have previously reported the prognostic significance of ER $\beta$ isoforms in British breast cancer TMAs [10]. Nuclear expression of ER $\beta 2$ is associated with a good prognosis in Caucasians with breast cancer. The proportion of ER $\beta 1$ and ER $\beta 2$ positivity (62 and $57 \%$, respectively) in the Nigerian breast cancer cohort was much lower than in the British cohort (98.7 and 83\%, respectively). Regrettably, follow-up data were sparse in all the study centres, and so it has not been possible to carry out a survival analysis.

In this study, almost a quarter of the Nigerian breast cancer cases showed a high proliferative index. Agboola et al. [18] reported a higher percentage (82.6\%) of Ki67positive tumours in Nigerian breast cancer cases associated with negative hormone receptor status and a positive association with basal CKs.

In this series, in contrast to the Caucasian cancer cases, we report a very high proportion of E-cadherin negativity in non-lobular carcinoma, previously reported in another study [35]. E-cadherin negativity in non-lobular breast cancer in Caucasians is uncommon (7.2\%) and has been shown to be associated with poor prognostic indicators
Titloye et al. 
Table 4. Results of studies on ER/PR/HER2 expression in indigenous populations in sub-Saharan Africa

\begin{tabular}{|c|c|c|c|c|c|c|c|c|c|c|}
\hline Country & Nigeria & Nigeria & $\begin{array}{l}\text { South } \\
\text { Africa }\end{array}$ & Ghana & Kenya & Nigeria & Nigeria & Ghana & Sudan & Mali \\
\hline $\begin{array}{l}\text { Study } \\
\text { sample } \\
\text { type }\end{array}$ & $\begin{array}{l}\text { full- } \\
\text { section, } \\
\text { TMA }\end{array}$ & TMA & $\begin{array}{l}\text { (data } \\
\text { review) }\end{array}$ & $\begin{array}{l}\text { full- } \\
\text { section }\end{array}$ & $\begin{array}{l}\text { full- } \\
\text { section }\end{array}$ & $\begin{array}{l}\text { full- } \\
\text { section }\end{array}$ & $\begin{array}{l}\text { full- } \\
\text { section }\end{array}$ & $\begin{array}{l}\text { full- } \\
\text { section }\end{array}$ & $\begin{array}{l}\text { full- } \\
\text { section, } \\
\text { TMA }\end{array}$ & $\begin{array}{l}\text { full- } \\
\text { section }\end{array}$ \\
\hline Sample size, $\mathrm{n}$ & 835 & 308 & 1,200 & $\begin{array}{l}330 \\
57(\mathrm{IHC})\end{array}$ & 129 & 192 & 89 & 75 & 67 & 114 \\
\hline Mean age & $\begin{array}{l}49 \text { yrs } \\
85 \% \\
\text { were } \\
<51 \text { yrs }\end{array}$ & $\begin{array}{l}- \\
61 \% \\
\text { were } \\
<51 \text { yrs }\end{array}$ & $\begin{array}{l}40 \% \\
\text { were } \\
<50 \text { yrs }\end{array}$ & $\begin{array}{l}49 \text { yrs } \\
73 \% \text { were } \\
\text { pre- } \\
\text { menopause }\end{array}$ & 48 yrs & n.s. & $\begin{array}{l}48 \text { yrs } \\
54 \% \\
\text { were } \\
<50 \text { yrs }\end{array}$ & $48 \mathrm{yrs}$ & $54.8 \mathrm{yrs}$ & 46 yrs \\
\hline $\begin{array}{l}\text { Positive } \\
\text { nodal } \\
\text { status }\end{array}$ & 91 & 92 & n.s. & n.s. & 72 & n.s. & n.s. & n.s. & 70 & 89 \\
\hline $\mathrm{ER} \alpha-$ & 78 & 79 & 35 & 53 & 76 & 27 & 62 & 76 & $55 / 34$ & 61 \\
\hline PR- & 81 & 72 & 47 & 87 & & 30 & 79 & 67 & $43 / 24$ & 72 \\
\hline HER2- & 81 & 82 & 74 & 80 & 74 & 80 & 96 & 96 & $\begin{array}{l}88 \text { TMA, } \\
85 \text { full- } \\
\text { section }\end{array}$ & 82 \\
\hline
\end{tabular}

Values expressed as percentages, unless otherwise indicated. $-=$ Negative; $+=$ positive. n.s. $=$ not stated; yrs $=$ years.

including a large tumour size, a high histological grade, negative hormone receptors and reduced survival [36].

\section{Conclusions}

This paper provides a detailed analysis of the histological and molecular features of Nigerian breast cancer. It occurs at a younger age and is predominantly triple- negative and non-basal. This molecular profile indicates an aggressive phenotype which appears to be similar to other African cases but distinct from the Western counterpart. This should be considered when planning management strategies for patients and it calls for improvements that will facilitate early detection of breast cancer in African women who are likely to develop this aggressive disease at a young age. 


\section{Acknowledgement}

This work was funded by a grant for AMS from Breast Cancer Research Trust. The authors are grateful to Prof. Ojo for donating some tumour tissue samples to the study, Mr. Iyiola, Mr. Aremu for technical assistance with retrieving tumour blocks. N.A.T. was supported by UICC-ICRETT grants. The authors thank Dr. A. Piskorski for contributing to the scoring.

\section{Disclosure Statement}

There were no conflicts of interest.

\section{References}

1 Hausauer AK, Keegan TH, Chang ET, Clarke CA: Recent breast cancer trends among Asian/Pacific Islander, Hispanic, and African-American women in the USA: changes by tumor subtype. Breast Cancer Res 2007; 9:R90.

2 Li CI, Malone KE, Daling JR: Differences in breast cancer stage, treatment, and survival by race and ethnicity. Arch Intern Med 2003; 163:49-56.

3 Li CI, Malone KE, Daling JR: Differences in breast cancer hormone receptor status and histology by race and ethnicity among women 50 years of age and older. Cancer Epidemiol Biomarkers Prev 2002;11:601-607.

4 Newman LA, Bunner S, Carolin K, et al: Ethnicity related differences in the survival of young breast carcinoma patients. Cancer 2002;95:21-27.

5 Brown LA, Hoog J, Chin SF, et al: ESR1 gene amplification in breast cancer: a common phenomenon? Nat Genet 2008;40:806-807.

6 Nggada HA, Yawe KD, Abdulazeez J, Khalil MA: Breast cancer burden in Maiduguri, northeastern Nigeria. Breast J 2008;14:284286.

7 Bird PA, Hill AG, Houssami N: Poor hormone receptor expression in East African breast cancer: evidence of a biologically different disease? Ann Surg Oncol 2008;15: 1983-1988.

8 Adebamowo CA, Famooto A, Ogundiran TO, et al: Immunohistochemical and molecular subtypes of breast cancer in Nigeria. Breast Cancer Res Treat 2008;110:183-188.

9 NHS Cancer Screening Programmes, Royal College of Pathologists: Pathology Reporting of Breast Disease 2005.

10 Shaaban AM, Green AR, Karthik S, et al: Nuclear and cytoplasmic expression of ERbeta1, ERbeta2, and ERbeta5 identifies distinct prognostic outcome for breast cancer patients. Clin Cancer Res 2008;14:5228-5235.

11 Pinder SE, Brown JP, Gillett C, et al: The manufacture and assessment of tissue microarrays: suggestions and criteria for analysis, with breast cancer as an example. J Clin Pathol 2013;66:169-177.

12 Shaaban AM, Ball GR, Brannan RA, et al: A comparative biomarker study of 514 matched cases of male and female breast cancer reveals gender-specific biological differences. Breast Cancer Res Treat 2012;133:949-958.
13 Perou CM, Sorlie T, Eisen MB, et al: Molecular portraits of human breast tumours. Nature 2000;406:747-752.

14 Callagy G, Cattaneo E, Daigo Y, et al: Molecular classification of breast carcinomas using tissue microarrays. Diagn Mol Pathol 2003; $12: 27-34$.

15 Abd El-Rehim DM, Ball G, Pinder SE, et al: High-throughput protein expression analysis using tissue microarray technology of a large well-characterised series identifies biologically distinct classes of breast cancer confirming recent cDNA expression analyses. Int J Cancer 2005;116:340-350.

16 Abd El-Rehim DM, Pinder SE, Paish CE, et al: Expression of luminal and basal cytokeratins in human breast carcinoma. J Pathol 2004; 203:661-671.

17 Gnant M, Thomssen C, Harbeck N: St. Gallen/Vienna 2015: a brief summary of the consensus discussion. Breast Care (Basel) 2015; 10:124-130.

18 Agboola AJ, Musa AA, Wanangwa N, et al: Molecular characteristics and prognostic features of breast cancer in Nigerian compared with UK women. Breast Cancer Res Treat 2012;135:555-569.

19 McCormack VA, Joffe M, van den Berg E, et al: Breast cancer receptor status and stage at diagnosis in over 1,200 consecutive public hospital patients in Soweto, South Africa: a case series. Breast Cancer Res 2013;15:R84.

20 Ohene-Yeboah M, Adjei E: Breast cancer in Kumasi, Ghana. Ghana Med J 2012;46:8-13.

21 Titiloye N, Omoniyi-Esan G, Adisa A, et al: Breast cancer in a Nigerian cohort: histopathology, immunohistochemical profile and survival. Postgrad Med J Ghana 2013;2:8386.

22 Stark A, Kleer CG, Martin I, et al: African ancestry and higher prevalence of triple-negative breast cancer: findings from an international study. Cancer 2010;116:4926-4932.

23 Awadelkarim KD, Arizzi C, Elamin EO, et al: Tissue microarray (TMA) versus whole section immunohistochemistry in the assessment of ER/PR and Her-2/neu status in a breast cancer series from Sudan. Breast J 2013; 19:446-447.

24 Ly M, Antoine M, Dembele AK, et al: High incidence of triple-negative tumors in subsaharan Africa: a prospective study of breast cancer characteristics and risk factors in Ma- lian women seen in a Bamako university hospital. Oncology 2012;83:257-263.

25 Rambau PF, Chalya PL, Manyama MM, Jackson KJ: Pathological features of breast cancer seen in northwestern Tanzania: a nine years retrospective study. BMC Res Notes 2011;4: 214.

26 Bowen RL, Duffy SW, Ryan DA, Hart IR, Jones JL: Early onset of breast cancer in a group of British black women. Br J Cancer 2008;98:277-281.

27 Ingleby JD: Early onset of breast cancer in Black British women: how reliable are the findings? Br J Cancer 2008;99:986-987.

28 National Cancer Intelligence Unit: Second All Breast Cancer Report. http://www.cancerscreening.nhs.uk/breastscreen/second-allbreast-cancer-report.pdf (2011).

29 Gukas ID, Jennings BA, Mandong BM, et al: A comparison of the pattern of occurrence of breast cancer in Nigerian and British women. Breast 2006; 15:90-95.

30 Cancer Research UK: Breast cancer incidence statistics, 2013

31 McCormack VA, Perry N, Vinnicombe SJ, Silva Idos S: Ethnic variations in mammographic density: a British multiethnic longitudinal study. Am J Epidemiol 2008;168:412-421.

32 Phipps AI, Buist DS, Malone KE, et al: Reproductive history and risk of three breast cancer subtypes defined by three biomarkers. Cancer Causes Control 2011;22:399-405.

33 Bauer KR, Brown M, Cress RD, Parise CA, Caggiano V: Descriptive analysis of estrogen receptor (ER)-negative, progesterone receptor (PR)-negative, and HER2-negative invasive breast cancer, the so-called triple-negative phenotype: a population-based study from the California Cancer Registry. Cancer 2007;109:1721-1728.

34 Aapro M, Wildiers H: Triple-negative breast cancer in the older population. Ann Oncol 2012;23(suppl 6):vi52-vi55.

35 Agboola AO, Banjo AA, Anunobi CC, et al: Cell proliferation (KI-67) expression is associated with poorer prognosis in Nigerian compared to British breast cancer women. ISRN Oncol 2013:675051.

36 Rakha EA, Abd El Rehim D, Pinder SE, Lewis SA, Ellis IO: E-cadherin expression in invasive non-lobular carcinoma of the breast and its prognostic significance. Histopathology 2005;46:685-693. 